\title{
Osteosynthesis techniques used for mandibular sagittal split osteotomy - history of orthognathic procedures and modern practice
}

\section{Zespolenia kości stosowane przy strzałkowej osteotomii gałęzi i trzonu żuchwy - od pierwszych zabiegów chirurgii ortognatycznej, aż po współczesność}

\author{
Rafał Nowak $^{1 凶}$, Grzegorz Trybek ${ }^{2}$ \\ ${ }^{1}$ Uniwersytet Medyczny im. Piastów Śląskich we Wrocławiu, Katedra i Klinika Chirurgii Szczękowo-Twarzowej, ul. Borowska 213, 50-556 Wrocław \\ 2 Pomorski Uniwersytet Medyczny w Szczecinie, Zakład Chirurgii Stomatologicznej, al. Powstańców Wlkp. 72, 70-111 Szczecin \\ \rafal.nowak@chirurgiatwarzy.pl
}

\begin{abstract}
Choosing an appropriate fixation technique after maxillary or mandibular osteotomy is one of the key factors affecting the success of orthognathic surgery.

In line with the development of new surgical methods and techniques, the surgeons' approach to the fixation of bone fragments has evolved accordingly, varying from non-fusion to different osteosynthesis techniques. Advances in medical sciences and medical technologies, have changed our attitudes to bone fragment reduction in orthopaedics and traumatology, and also in maxillofacial surgery. The pivotal underlying principle which
\end{abstract}

determines bone healing - that is proper positioning so as to ensure appropriate contact area and immobilisation so as to ensure osteosynthesis - has remained unchanged for centuries. However, over the years, patient comfort and the predictability of treatment outcomes have vastly improved.

The paper provides an overview of the techniques and methods used for the fixation of osteotomized fragments after bilateral sagittal split osteotomy since its introduction by Hugo Obwegeser up to the present day.

Keywords: osteosynthesis; orthognathic surgery; bilateral sagittal split osteotomy; BSSO; bone fixation.

\begin{abstract}
ABSTRAKT
W chirurgii ortognatycznej jednym z czynników warunkujących powodzenie leczenia jest zastosowanie odpowiednich zespoleń po wykonaniu zabiegu osteotomii szczęki lub żuchwy.

Podobnie jak zmieniały się metody i techniki operacyjne, tak również ewaluowało podejście chirurgów do sposobów zespalania odłamów kostnych od pozostawiania ich bez zespalania do stosowania różnych technik osteosyntezy. Rozwój medycyny i technologii medycznej pozwolił zmienić podejście do unieruchamiania odłamów kostnych nie tylko w ortopedii i traumatologii, ale również przy planowych kostnych zabiegach korekcyjnych. Naczelna zasada warunkująca
\end{abstract}

gojenie kości - czyli jej prawidłowe ustawienie, tak aby zapewnić właściwą powierzchnię przylegania, oraz unieruchomienie, aby umożliwić zrost - pozostała od wieków niezmienna, natomiast dzięki postępowi możliwe stało się zwiększenie komfortu pacjenta i przewidywalności efektów leczenia.

W artykule przedstawiono techniki i sposoby zespalania odłamów osteotomijnych po wykonaniu strzałkowej osteotomii gałęzi żuchwy, począwszy od pierwszych zabiegów wykonywanych przez Hugo Obwegesera, aż do dzisiaj.

Słowa kluczowe: osteosynteza; chirurgia ortognatyczna; BSSO; osteotomia korekcyjna żuchwy; zespolenie kości.

\section{INTRODUCTION}

Contemporary orthognathic surgery involves, depending on the type and severity of the skeletal defect, either the upper face (maxilla, zygomatic bones, orbits, nasal bones) or the lower face (mandible); the procedures involving the upper and lower face can also be performed simultaneously.

It should be emphasized that the transoral approach is preferred nowadays, since it does not leave visible facial scarring.

The key issues in mandibular reconstruction are to cut (osteotomy) or to remove (ostectomy) the appropriate bone segment, and to reposition the mandible as predetermined, which enables achieving proper occlusal relationships, and

\section{WSTĘP}

We współczesnej chirurgii ortognatycznej, w zależności od rodzaju i nasilenia wady gnatycznej, zabiegi korekcyjne obejmują albo górny masyw twarzy - szczęki, kości jarzmowe, oczodoły, kości nosa, albo masyw dolny - żuchwę; zabiegi obejmujące górny i dolny masyw twarzy wykonuje się także jednoczasowo.

Należy zaznaczyć, że w chirurgii ortognatycznej preferowany jest dostęp wewnątrzustny, aby nie pozostawiać widocznych blizn na twarzy.

W leczeniu zniekształceń żuchwy naczelną zasadą jest przecięcie (osteotomia) lub wycięcie (ostectomia) odpowiedniego 
in most cases improves facial aesthetics. The resulting mandibular segments are fixed in a new alignment to ensure their correct union.

Surgical mandibular correction may be divided in terms of the approach into transoral and extraoral procedures, while in terms of anatomy it may be divided into the procedures involving the ramus, body or condylar process of the mandible. Of the numerous surgical methods and their modifications, the ones performed through the transoral approach have become most appreciated. Although more challenging technically and requiring special tools, it has one main advantage: it does not leave visible facial scarring. Surgical methods and techniques used for treating mandibular malformations have changed over the years, yet the method of mandibular sagittal split ramus osteotomy proposed in 1955 by Hugo Obwegeser [1] has undoubtedly become the canon of orthognathic surgery, and it is still the method of choice.

The mandibular sagittal split ramus osteotomy has evolved, although its main assumptions have remained unchanged, and so have the way of thinking and the fixation techniques of the osteotomized bone segments, which have advanced from external fixation to the different osteosynthesis techniques used in modern times.

\section{THE PAST}

Before Hugo Obwegeser (Fig. 1) postulated his mandibular sagittal split ramus osteotomy (the first procedure was done on February $17^{\text {th }}, 1953$ ) various surgical techniques were applied for mandibular repair, which involved mandibular osteotomy at the appropriate site, followed by the repositioning and realignment of bone segments. Regardless of the osteotomy site or the approach, the common feature of all these procedures was that they used external fixation, i.e. either rigid intermaxillary fixation or orthopaedic fixation devices.

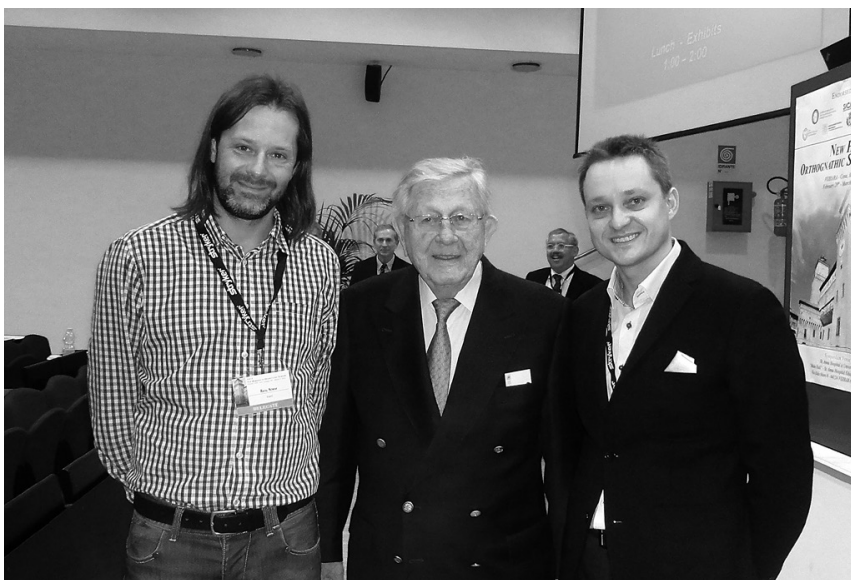

FIGURE 1. Professor Hugo Obwegeser (in the middle) and co-author Rafał Nowak PhD (left side) accompanied by Krzysztof Dowgierd PhD (right side); Ferrara, Italy, 2014

RYCINA 1. Profesor Hugo Obwegeser (pośrodku) oraz autorzy artykułu dr n. med. Rafał Nowak (po stronie lewej) i dr n. med. Krzysztof Dowgierd (po stronie prawej); Ferrara, Włochy, 2014 fragmentu kości i ustawienie żuchwy w nowym, zaplanowanym położeniu, co umożliwia uzyskanie prawidłowych warunków zgryzowych i w większości przypadków poprawę estetyki twarzy. Powstałe odłamy osteotomijne żuchwy unieruchamia się natomiast w nowym położeniu, aby uzyskać ich prawidłowy zrost.

Ze względu na dostęp chirurgiczny metody operacyjnego leczenia zniekształceń żuchwy można podzielić na wewnątrzustne i zewnątrzustne, a ze względów anatomicznych na zabiegi wykonywane w obrębie gałęzi, trzonu lub wyrostka kłykciowego żuchwy. Z wielu różnych metod operacyjnych oraz ich modyfikacji największe uznanie zyskały te, które są wykonywane z dostępu wewnątrzustnego. Dostęp ten, mimo że jest trudniejszy technicznie i wymaga specjalnych narzędzi, ma przede wszystkim tę zaletę, że nie pozostawia widocznych blizn na twarzy. W ciągu lat zmieniły się sposoby i techniki operacyjne wykorzystywane w leczeniu zniekształceń żuchwy, jednak nie ma wątpliwości, że metoda wewnątrzustnej strzałkowej osteotomii gałęzi żuchwy, zaproponowana w 1955 r. przez Hugo Obwegesera [1], weszła do kanonu chirurgii ortognatycznej i jest metodą z wyboru.

Podobnie jak ewoluowała sama metoda, choć jej założenia pozostały niezmienne, tak również zmieniała się technika unieruchamiania odłamów kostnych powstałych w trakcie zabiegów strzałkowej osteotomii gałęzi żuchwy. Początkowo stosowano unieruchomienia zewnętrzne, natomiast obecnie stosuje się różne typy osteosyntez.

\section{WCZORAJ}

Zanim Hugo Obwegeser (ryc. 1) zaproponował metodę strzałkowej osteotomii gałęzi żuchwy (pierwszy zabieg miał miejsce 17 lutego 1953 r.), w chirurgii korekcyjnej miały zastosowanie różne techniki operacyjne polegające na przecięciu żuchwy w odpowiednim miejscu i ustawieniu odłamów kostnych w nowej pozycji. Bez względu na to, w którym miejscu żuchwa była przecinana i jaki dostęp wykorzystywano, wspólną cechą tych zabiegów było stosowanie unieruchomień zewnętrznych albo w postaci sztywnego wiązania międzyszczękowego, albo za pomocą przyrządów ortopedycznych.

Idea stosowania unieruchomień bezpośrednich odłamów kostnych ma swój początek w traumatologii szczękowo-twarzowej, a ta z kolei w ortopedii.

Podstawową zasadą leczenia złamań kości jest prawidłowe ustawienie odłamów kostnych (tak aby uzyskać dobre przyleganie odpowiednich płaszczyzn do siebie) oraz zastosowanie unieruchomienia wewnętrznego lub zewnętrznego, które z kolei umożliwia utrzymanie ich w uzyskanym położeniu i powstanie prawidłowego zrostu kostnego.

Już od czasów starożytnych w złamaniach kości długich stosowano różnego rodzaju unieruchomienia zewnętrzne, ale idea otwartego ich leczenia techniką bezpośredniego zespalania odłamów pojawiła się dopiero w XIX w. Również w przypadku urazów twarzoczaszki do XIX w. powszechnie stosowaną metodą były unieruchomienia zewnętrzne. 
The idea of a direct internal osteosynthesis originated in maxillofacial traumatology, which in turn stemmed from orthopaedics.

The fundamental principle in the treatment of bone fractures is to reduce bone segments properly so as to achieve their good alignment, and to use internal or external fixation, which keeps the segments stable until the bone healing process is complete.

Since ancient times various external fixation techniques have been used in long bone fractures. However, the idea of fracture reduction with direct, internal fixation did not emerge until the $19^{\text {th }}$ century. Similarly, in craniofacial injuries external fixation was the most common fracture treatment until the $19^{\text {th }}$ century.

The first successful humerus fracture reduction with internal silver wire fixation was performed by Rodgers, a New York surgeon, in 1827. The first reported case of the surgical reduction of a mandibular fracture was the one by Baudens, a French military surgeon (Fig. 2) who devised an internal fixation method using circumferential wiring in the 1840s. Direct fixation of a compound mandibular fracture with silver wire ligatures was first used by Thomas in 1867 .

Albin Lambotte (Fig. 3) coined the term "osteosynthesis" and introduced a number of innovations to the surgical reduction of fractures, both of long bones and of the mandible. Furthermore, he designed a set of instruments and aluminium plates to immobilise bone segments. Sir Arbuthnot William Lane is also believed to be the pioneer in using direct skeletal fixation in the management of fractures [2].

According to some sources, mandibular plate fixation was first described by Hansmann, a surgeon from Hamburg in 1886 [2]. Other sources, though, state that the first internal fixation of a mandibular fracture was performed in 1917 by the German general surgeon Soerensen, who used a wedding ring to make a plate for the stabilization of mandibular segments [3].

With the increasing knowledge and awareness of aseptics and antiseptics and, above all, with the development of anaesthesiology, surgeons were more likely to use surgical techniques of fracture reduction in the treatment of both long

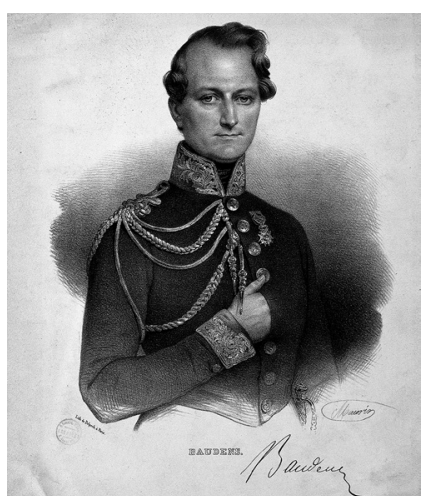

FIGURE 2. / RYCINA 2.

Jean Baptiste Lucien Baudens (1804-1857); lithograph by NE Maurin www.wellcomeimages.org (www.wellcomeimages.org) /

litografia NE Maurin

(źródło: www.wellcomeimages.org)
Pierwszego udanego zespolenia odłamów kości ramiennej przy użyciu srebrnego drutu dokonał w 1827 r. nowojorski chirurg Rodgers. Natomiast pierwszym znanym sposobem operacyjnego leczenia złamania żuchwy było założenie wiązania okolnego. Dokonał tego francuski chirurg wojskowy Baudens (ryc. 2) w 1840 r. Z kolei bezpośrednie zespolenie odłamów kostnych za pomocą drutu zastosował Thomas w $1867 \mathrm{r}$.

Autorem pojęcia „ostoesynteza” był Albin Lambotte (ryc. 3), który wprowadził także wiele innowacji do operacyjnego leczenia złamań nie tylko kości długich, ale i w obrębie żuchwy. Wprowadził również zestaw narzędzi i płytek aluminiowych do unieruchamiania jej odłamów. Za prekursora stosowania bezpośrednich zespoleń w leczeniu złamań uważany jest również sir Arbuthnot William Lane [2].

Według jednych źródeł zastosowanie metalowej płytki do leczenia złamania żuchwy opisał po raz pierwszy w $1886 \mathrm{r}$. pochodzący z Hamburga Hansmann [2]. Inne źródła podają, że pierwsze zespolenie płytkowe wykonał niemiecki chirurg ogólny Soerensen w 1917 r., wykorzystując do tego celu obrączkę ślubną, z której zrobił płytkę do zespolenia odłamów żuchwy [3].

Wraz z poznaniem zasad aseptyki i antyseptyki, a przede wszystkim rozwojem anestezjologii, chirurdzy coraz częściej sięgali po metody operacyjne w leczeniu złamań zarówno kości długich, jak i kości twarzoczaszki. Jednak na radykalną zmianę w sposobie leczenia złamań kości twarzoczaszki, a wtórnie na nowe sposoby zespalania odłamów osteotomijnych w chirurgii ortognatycznej trzeba było poczekać aż do lat 70. XX w. Wtedy to w traumatologii szczękowo-twarzowej dokonał się przełom związany z wprowadzeniem do leczenia złamań zminiaturyzowanych płytek $[4,5]$ i poznaniem najkorzystniejszych miejsc umieszczania ich w kości [6]. W różnych udoskonaleniach i modyfikacjach minipłytki są stosowane do dziś, a producenci na podstawie badań biomechanicznych i klinicznych opracowali nawet standardowe zestawy do leczenia poszczególnych rodzajów złamań [7, 8, 9].

Zagadnienie odpowiedniej stabilizacji odłamów kostnych po zabiegu strzałkowej osteotomii gałęzi żuchwy poruszyło w swoich opracowaniach wielu autorów [10,11,12, 13]. Obwegeser [1], autor metody strzałkowej osteotomii gałęzi żuchwy, stabilizował odłamy po rozszczepieniu wiązaniem ligaturowym wykonanym wokół gałęzi lub też zakładał szwy kostne na jej przednim brzegu (ryc. 4). Początkowo jednak pozostawiał fragmenty kostne bez żadnej stabilizacji i stosował tylko wiązanie międzyszczękowe.

Z kolei Epker [14] zaproponował umieszczenie szwu kostnego na górnym brzegu odłamów kostnych, ale pierwotnie postępował podobnie jak Obwegeser i same odłamy kostne nie były unieruchamiane. Natomiast Booth [15] zakładał szew kostny na dolnym brzegu trzonu żuchwy, co techniczne wydaje się być jednak znacznie trudniejsze. MacIntosh [16] zastosował wiązanie ligaturowe w postaci szwów okolnych wokół obu odłamów kostnych. Poza tym wszyscy autorzy oprócz bezpośrednich unieruchomień odłamów osteotomijnych zakładali także na okres 4-6 tygodni po zabiegu operacyjnym wiązania międzyszczękowe. 
bone and craniofacial fractures. However, the real shift in the management of craniofacial bones fractures which led to new developments in osteotomized segment fixation in orthognathic surgery only took place in the 1970s. This was when miniplates were introduced in maxillofacial traumatology for osteosynthesis $[4,5]$ and when the optimum fixation sites were identified [6]. Having undergone numerous improvements and modifications, miniplates have been used up to the present, and based on biomechanical and clinical studies manufacturers have even developed standard instrument sets suitable for individual types of fractures [7, 8, 9].

Many authors have addressed the issue of ensuring the appropriate fixation of bone segments after sagittal split ramus osteotomy in their papers $[10,11,12,13]$. Obwegeser [1], the previously mentioned author of the sagittal split ramus osteotomy procedure, used ligature wires placed circumferentially around the ramus, or inserted wire sutures in the anterior ramus (Fig. 4). However, he initially left osteotomized segments without any internal rigid fixation, using intermaxillary fixation instead.

Epker [14] in turn proposed inserting the wire suture in the upper edge of the osteotomy segments. However, initially, like Obwegeser, he did not immobilise the bone segments. Booth [15] inserted the wire suture along the lower edge of the mandibular body, which seems a real technical challenge, whereas MacIntosh [16] used a circummandibular steel wire ligature for the stabilisation of both bone segments. Moreover, along with direct fixation of osteotomized segments, all authors used intermaxillary fixation for 4-6 weeks postoperatively.

A breakthrough in the approach to bone segment fixation after the Obwegeser - Dal Pont mandibular sagittal split ramus osteotomy was seen when the principles of stable osteosynthesis and the first compression osteosynthesis with bicortical screws were introduced to orthognathic surgery [17]. The author of this idea also departed from intermaxillary fixation because he believed that the rigid fixation itself was sufficient to ensure proper bone union. He also thought that such techniques would significantly decrease the relatively high recurrence rates in patients after mandibular repair surgery. At first his idea evoked little enthusiasm among surgeons treating skeletal defects, and Obwegeser himself was very critical of this method, which was visible during discussions at international conferences of maxillofacial surgeons [3].

At the same time, a revolution in maxillofacial trauma surgery was taking place after Michelet, Peri and Champy introduced a set of miniplates for stable osteosynthesis.

Another important step in the domain of osteotomy segment fixation involved improving the miniplate set originally designed in 1972-1973 in France by Michelet, Festal and Peri for facial fracture repair, and its application in orthognathic surgery [18]. This idea was also widely criticised by surgeons and stirred up heated discussions. The facts, however, spoke for themselves: in clinical follow-up stable osteosynthesis caused better bone segment alignment, which ensured their better union and lower risk of relapse. Furthermore, with this technique intermaxillary fixation could be avoided, which was

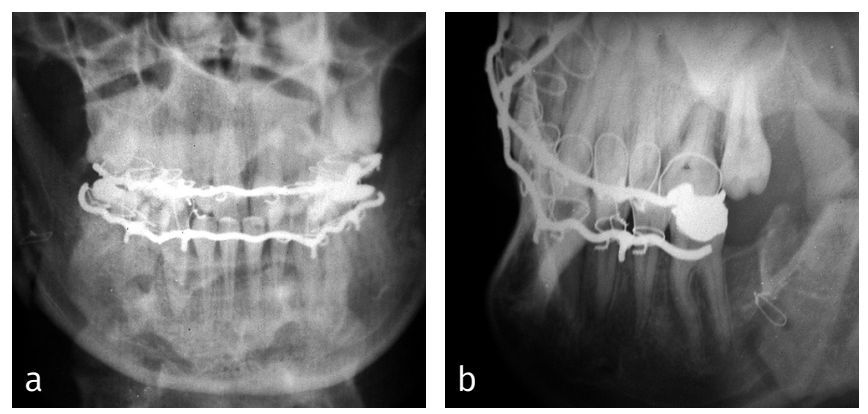

FIGURE 4. Osteosyntesis achieved with wire sutures of the mandible: a) AP radiograph; b) lateral radiograph

RYCINA 4. Stabilizacja odłamów kostnych za pomocą szwu kostnego widoczna na zdjęciach rentgenowskich: a) AP żuchwy; b) bocznym żuchwy

Przełom w sposobie zespalania odłamów osteotomijnych powstałych po rozszczepieniu gałęzi żuchwy metodą Obwegesera - Dal Ponta dokonał się wraz z wprowadzeniem do chirurgii ortognatycznej zasad osteosyntezy stabilnej i pierwszego kompresyjnego ich zespolenia za pomocą wkrętów bikortykalnych [17]. Pomysłodawca tego sposobu odstąpił także od unieruchomienia międzyszczękowego, gdyż uważał, że już sama sztywna osteosynteza wystarczy, aby zrost odłamów kostnych był prawidłowy. Sądził również, że zastosowanie tych technik w istotny sposób wpłynie na zmniejszenie częstości występowania wznów, które dotychczas często towarzyszyły zabiegom korekcyjnym wykonywanym w obrębie żuchwy. Początkowo jego pomysł spotkał się z niewielkim uznaniem w środowisku chirurgów zajmujących się leczeniem wad gnatycznych, a sam Obwegeser był nastawiony bardzo krytycznie do tej metody, co miało odzwierciedlenie w dyskusjach podczas międzynarodowych konferencji chirurgów szczękowo-twarzowych [3].

W tym czasie nastąpił również przełom w traumatologii szczękowo-twarzowej, gdy Michelet, Peri i Champy wprowadzili zestawy minipłytek do osteosytnezy stabilnej.

Drugim ważnym krokiem w dziedzinie zespoleń odłamów osteotomijnych było udoskonalenie stworzonego przez Micheleta, Festala i Periego w latach 1972-1973 we Francji zestawu minipłytek do leczenia złamań kości twarzy oraz wykorzystanie tych zespoleń przy zabiegach z zakresu chirurgii ortognatycznej [18]. Również i ten pomysł spotkał się z ogromną krytyką środowiska i wywołał burzliwe dyskusje. Fakty jednak przemawiały same za siebie - w obserwacjach klinicznych stabilna osteosynteza powodowała lepsze przyleganie do siebie odłamów osteotomijnych i tym samym zapewniała pewniejszy ich zrost oraz mniejsze ryzyko wznowy. Poza tym po zastosowaniu tej techniki można było również zrezygnować z zakładania unieruchomienia międzyszczękowego, co dawało większy komfort pacjentowi, i co najważniejsze większe bezpieczeństwo, ponieważ w momencie ekstubacji, po zakończeniu zabiegu, zapewniony był dostęp do jamy ustnej, co umożliwiało pełną kontrolę dróg oddechowych. To właśnie dlatego kolejni lekarze zajmujący się chirurgią ortognatyczną udoskonalali i modyfikowali techniki osteosyntezy stabilnej zaproponowane przez Spiessla i Luhra i podążali wytyczoną przez nich drogą. 
more comfortable for the patient and, most importantly, safer because after patient extubation at the end of the procedure the access to the oral cavity was unobstructed, which enabled full control of the respiratory tract. This was the reason why successive doctors working in orthognathic surgery have improved and modified the stable osteosynthesis techniques put forward by Spiessl and Luhr and followed their path.

\section{THE PRESENT}

In modern orthognathic surgery it is usually the surgeon who decides which bone fixation technique will be used, and nobody questions the applicability of the internal fixation, as with time sufficient evidence was obtained to unequivocally resolve the conflict in favour of osteosynthesis. As a standard, titanium fixation devices (screws, plates) of different sizes are used for osteosynthesis. However, different grade titanium or titanium alloys can be used for manufacturing fixation devices, which affects their mechanical properties, elastic modulus, flexibility and strength.

According to the Association for Osteosynthesis/Association for the Study of Internal Fixation, the leading organisation in the field of research in osteosynthesis two main osteosynthesis types can be identified: rigid fixation and functionally stable fixation.

Rigid fixation is a type of osteosynthesis which ensures full stability of bone fragments, preventing their mobility or dislocation. As a result, bone union is achieved in a predefined position as predetermined during the surgery. A typical example of rigid fixation used in order to immobilise bone segments during bilateral sagittal split osteotomy (BSSO) involves inserting bicortical screws (Fig. 5) of appropriate length (most frequently 11-15 $\mathrm{mm}$ ) so that they pass through both segments pushing them against each other [19].

Its advantages include ensuring rigid fixation without the need to add either rigid intermaxillary fixation or elastic intermaxillary tractions, and quick application. Bicortical screw fixation eliminates the gap between the segments and ensures their complete immobilisation. As a result, it is very susceptible to even the smallest errors. That is why its opponents emphasize the risk of impairing mandibular mobility as a result of proximal segment malpositioning (condylar torque), or even the development of progressive condylar resorption [20, 21]. Furthermore, excessive compression of bone segments may adversely affect the function of the inferior alveolar nerve (ION) if the osteotomy split opens the mandibular canal and a part of the nerve is exposed.

From the technical and anatomical perspective, bicortical screws may be inserted via the transoral approach (Fig. 6), or via the transbuccal approach, with or without an instrument known as a transbuccal trocar or via transoral approach (Fig. 7). It should be noted that although the screw should optimally be inserted in the bone at a right angle (90 degrees), the allowed deviation from this value ranges even $20-45$ degrees [22]. The most typical screw configuration involves inserting 3 screws

\section{DZISIAJ}

Dzisiaj w chirurgii ortognatycznej wybór rodzaju zespolenia odłamów kostnych należy najczęściej do operatora. Nikt już nie dyskutuje nad słusznością stosowania unieruchomień wewnętrznych, gdyż historia rozstrzygnęła ten spór zdecydowanie na korzyść osteosyntezy. Standardem jest stosowanie zespoleń tytanowych (śrub, płytek) o różnych wymiarach. Sam tytan użyty do produkcji zespoleń może również należeć do różnych klas, co determinuje jego właściwości mechaniczne, sztywność, elastyczność czy wytrzymałość.

Według Association for Osteosynthesis/Association for the Study of Internal Fixation, jednej z głównych organizacji skupiającej badaczy zajmujących się osteosyntezą, współcześnie wyróżnia się dwa główne rodzaje osteosyntezy: osteosyntezę sztywną oraz osteosyntezę funkcjonalnie stabilną.

Osteosynteza sztywna to taki rodzaj zespolenia, który nie pozwala na jakikolwiek ruch odłamów kostnych wobec siebie i warunkuje ich zrost w takim ustawieniu, jakie uzyskano podczas zabiegu. Typowym przykładem zastosowania takiej osteosyntezy podczas zespolenia odłamów kostnych przy zabiegu BSSO (bilateral sagital split osteotomy) jest użycie śrub bikorykalnych o odpowiedniej długości (najczęściej 11-15 mm), tak żeby przechodząc przez obydwa odłamy, śruby dociskały je do siebie [19] (ryc. 5).

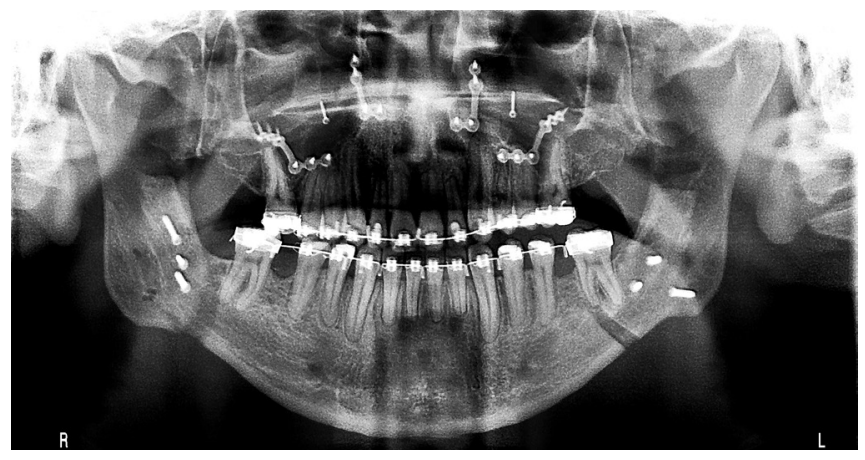

FIGURE 5. Bicortical screws in orthopantomogram

RYCINA 5. Śruby bikortykalne widoczne na zdjęciu rentgenowskim panoramicznym (OPG)

Zaletą tej metody jest sztywność zespolenia i możliwość całkowitego zrezygnowania z wiązań sztywnych czy wyciągów elastycznych międzyszczękowych, jak również szybka jej aplikacja. Metoda ta jednak nie wybacza błędów, nie pozwala na żadne ruchy odłamów wobec siebie. Dlatego jej przeciwnicy podkreślają możliwość wystąpienia zaburzeń ruchomości żuchwy na skutek nieprawidłowo wypozycjowanego fragmentu proksymalnego (condylar torque) czy nawet powstania postępującej resorpcji kłykcia [20, 21]. Dodatkowo zbyt mocna kompresja odłamów może niekorzystnie wpływać na funkcje nerwu zębodołowego dolnego, jeżeli ściany kostne kanału żuchwy znajdują się w obydwu odłamach i jest odsłonięty fragment nerwu.

Od strony technicznej i anatomicznej umieszczenie śrub bikortykalnych może odbyć się z dostępu przezpoliczkowego (ryc. 6) z użyciem lub bez użycia urządzenia zwanego trokarem przezpoliczkowym lub z dostępu wewnątrzustnego 

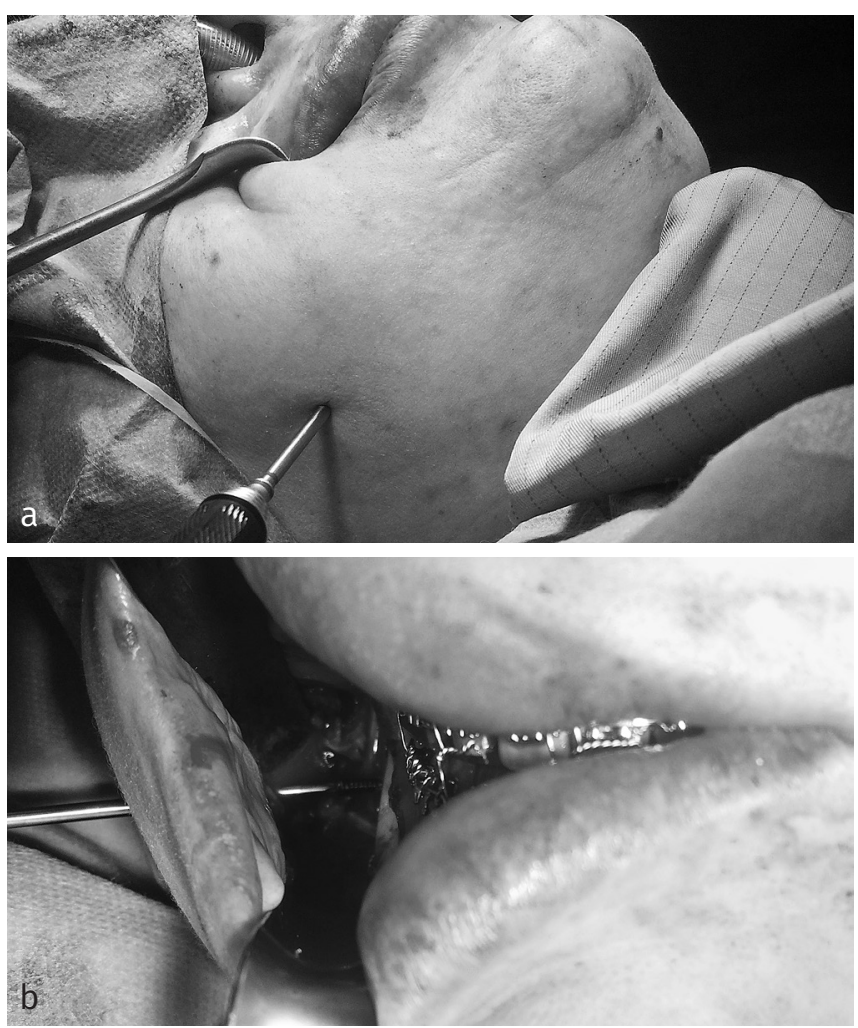

FIGURE 6. Transbuccal approach for bicortical screw fixation of mandibular osteotomy: a) extraoral view; b) intraoral view

RYCINA 6. Dostęp przezpoliczkowy podczas zespalania odłamów za pomocą śrub bikortykalnych: a) widok zewnątrzustny; b) widok wewnątrzustny

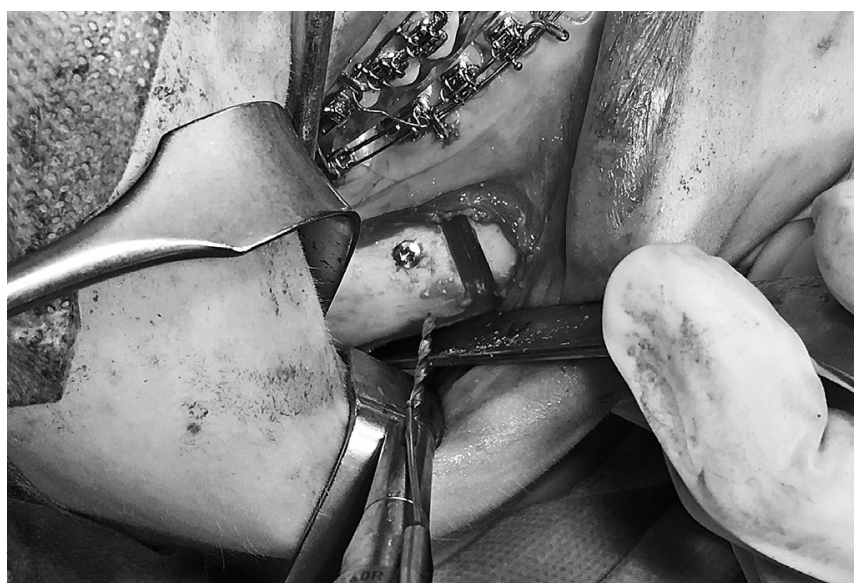

FIGURE 7. Transoral approach for bicortical screw fixation of mandibular osteotomy - intraoral view

RYCINA 7. Dostęp wewnątrzustny podczas zespalania odłamów za pomocą śrub bikortykalnych - widok wewnątrzustny

(Fig. 8), either all three along the upper edge of bone segments, or 2 screws along the upper edge and 1 below the mandibular canal, with the second option being more common due to biomechanical properties of fixation [23].

Functionally stable fixation is an osteosynthesis technique in which some minimum degree of movement is possible across the fracture gap, yet its range is limited so as not to interfere with the bone healing process. The

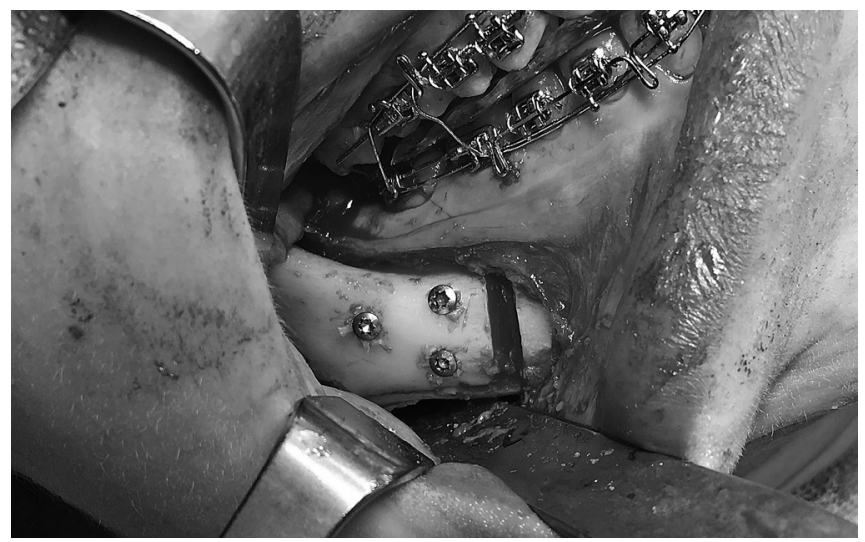

FIGURE 8. Bicortical screws in situ

RYCINA 8. Śruby bikortykalne in situ

(ryc. 7). Pamiętać należy, że optymalny kąt wprowadzenia śruby do kości wynosi $90^{\circ}$, jednak są dopuszczalne odchylenia nawet $20-45^{\circ}[22]$. Najczęstszy układ to umieszczenie 3 śrub na górnym brzegu odłamów lub 2 na górnym i 1 poniżej kanału żuchwy, ze wskazaniem na ten drugi ze względu na właściwości biomechaniczne zespolenia (ryc. 8) [23].

Funkcjonalna osteosynteza stabilna to taki rodzaj zespolenia odłamów kostnych, w którym dopuszczalne są minimalne ruchy odłamów wobec siebie, jednak na tyle ograniczone, że nie zaburzają procesu gojenia kości. Zespolenia monokortykalne (ryc. 9-11) z użyciem różnego rodzaju płytek traktuje się jako zespolenia funkcjonalne. Wyjątkiem tutaj może być użycie płytki o dużych wymiarach (tzw. load bearinig), która będzie pełnić funkcję osteosyntezy sztywnej.

Podobnie jak wybór rodzaju zespolenia, tak w przypadku zespolenia płytkowego wybór rodzaju, wielkości i kształtu płytki zależy od preferencji operatora. Producenci oferują specjalne zestawy dedykowane do zespoleń odłamów osteotomijnych żuchwy opartych o różne filozofie (ryc. 12), jednak w większości przypadków, za wyjątkiem wspomnianych wyżej różnic w kształcie płytek, główna zasada zespolenia pozostaje niezmienna - zespolenie ma być na tyle wydolne, żeby utrzymać odłamy we właściwym położeniu, pozwalając jedynie na minimalne ruchy odłamów wobec siebie. Skutkuje to mniejszą stabilnością w początkowym okresie zrostu i przy dyskrepancjach zgryzowych może być powodem większego przemieszczenia odłamów wobec siebie, a tym samym przyczyną wczesnej wznowy pooperacyjnej. Stwarza jednak większą swobodę i możliwość samoczynnego skorygowania się odłamu proksymalnego w przypadku jego przemieszczenia w stawie skroniowo-żuchwowym podczas zespalania odłamów.

Te przesłanki, czyli brak pewności co do pozycjonowania odłamu proksymalnego podczas zabiegu operacyjnego, gdy pacjent jest znieczulony i działają leki zwiotczające, leżały u podstaw filozofii zespolenia zaproponowanego przez autorów z Uniwersytetu w Munster (Niemcy) [24]. Główny zamysł polega na zastosowaniu płytki wykonanej z miękkiego tytanu o specyficznym kształcie. Po zespoleniu odłamów konieczne jest założenie na kilka dni sztywnego wiązania międzyszczękowego. 

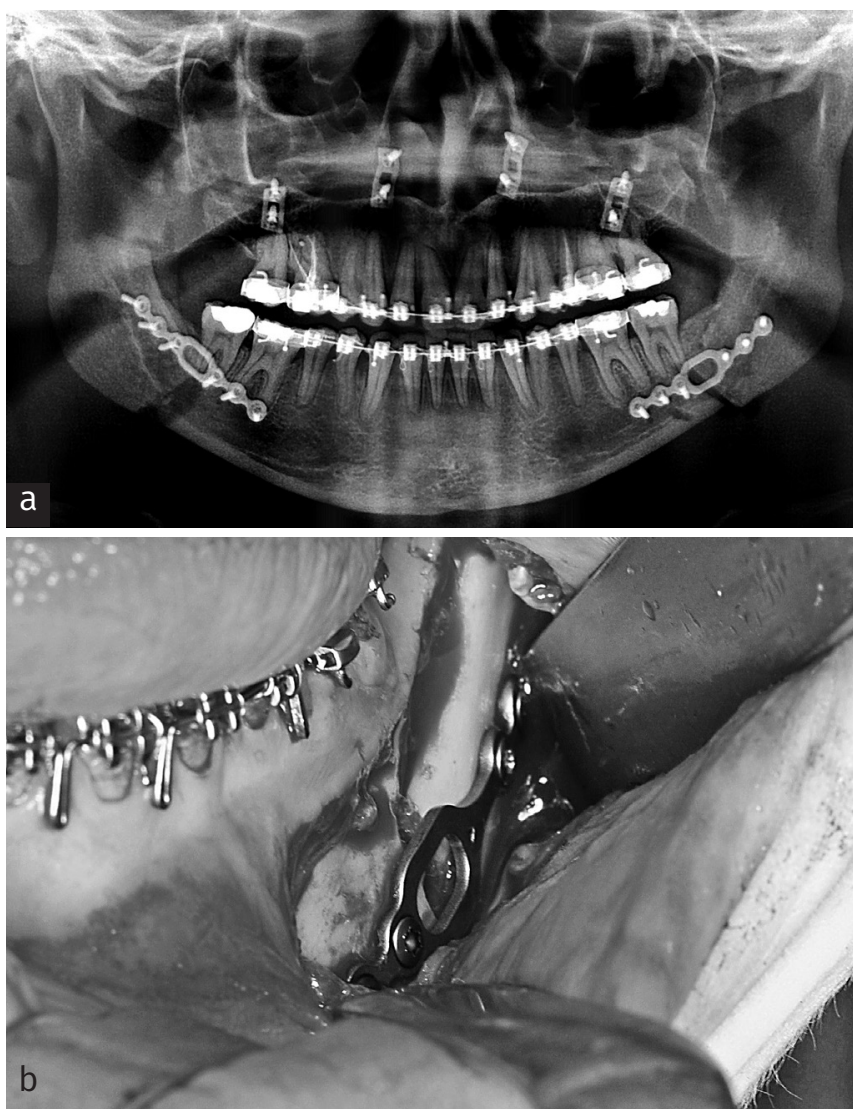

FIGURE 9. Monocortical fixation: a) double plate osteosynthesis in orthopantomogram; b) double plate osteosynthesis in situ

RYCINA 9. Zespolenie monokortykalne: a) płytka z podwójnym mostem zdjęcie rentgenowskie panoramiczne; b) płytka z podwójnym mostem in situ
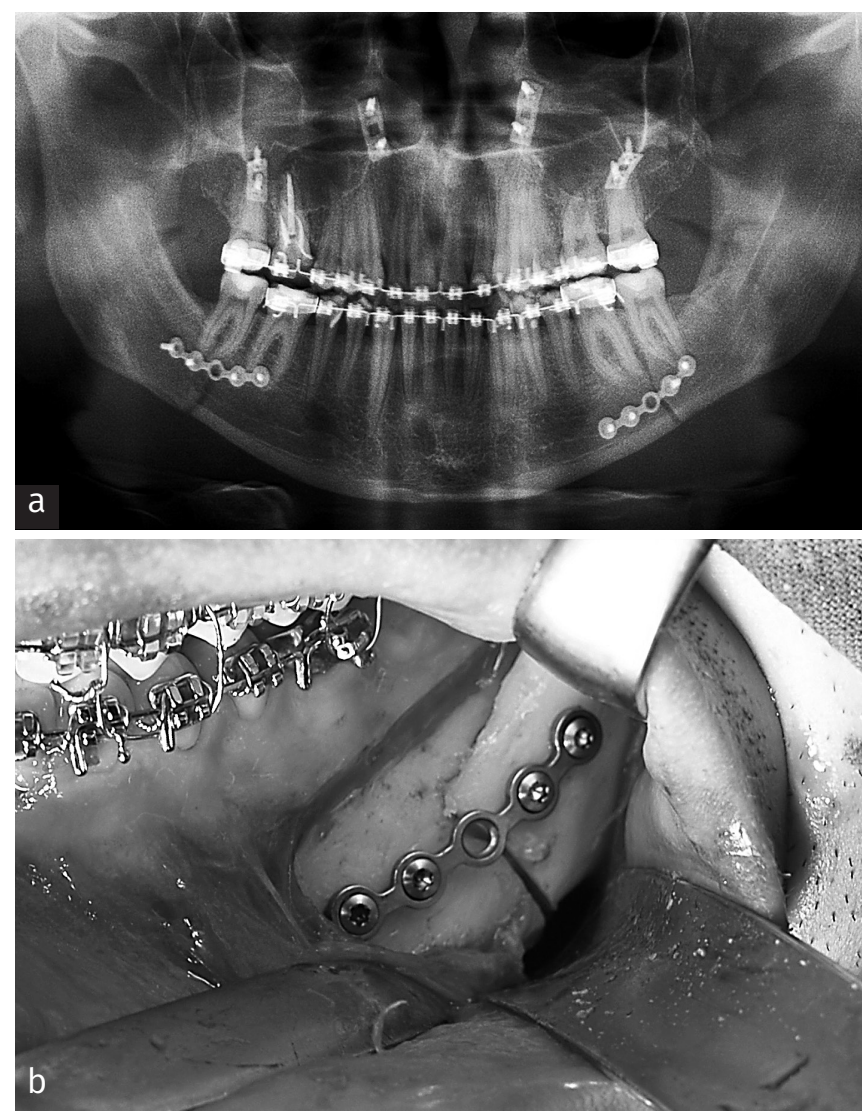

FIGURE 10. Monocortical fixation: a) single plate osteosynthesis in orthopantomogram; b) single plate osteosynthesis in situ

RYCINA 10. Zespolenie monokortykalne: a) płytka prosta - zdjęcie rentgenowskie panoramiczne; b) płytka prosta in situ
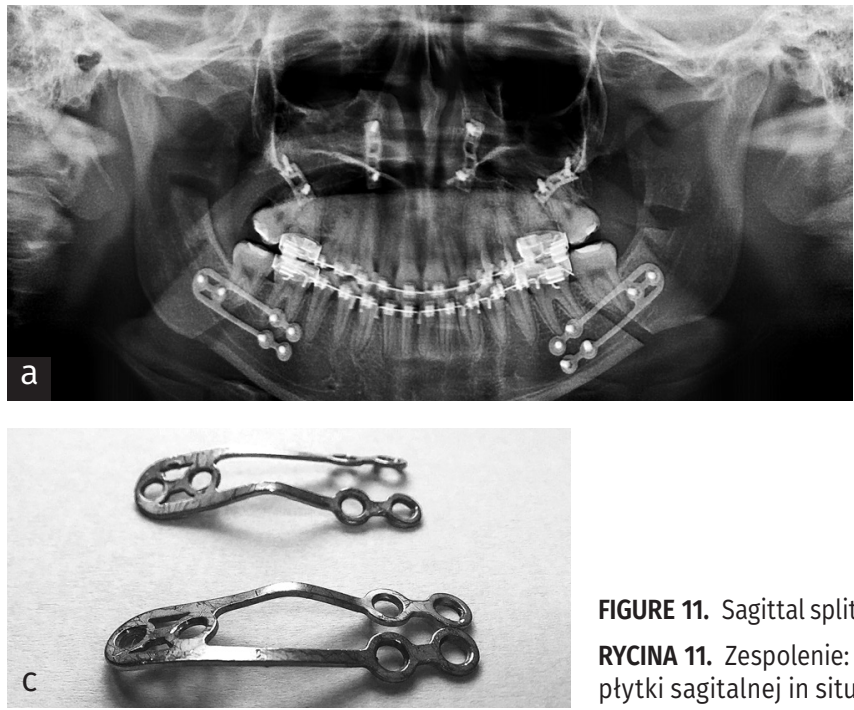

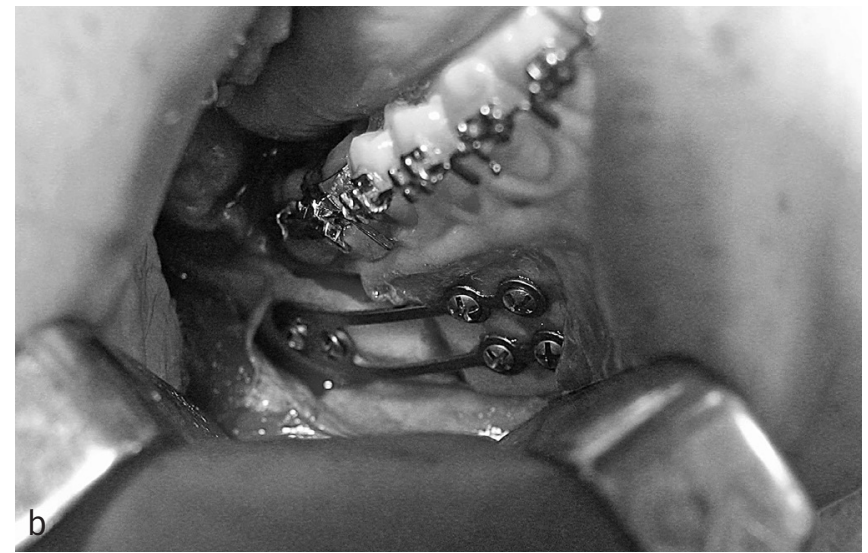

FIGURE 11. Sagittal split plate: a) in orthopantomogram; $b$ ) in situ; c) deformed fixation devices after removal RYCINA 11. Zespolenie: a) za pomocą płytki sagitalnej - zdjęcie rentgenowskie panoramiczne; b) za pomocą płytki sagitalnej in situ; c) odkształcone - widok po ewakuacji monocortical fixation with various types of plates (Fig. 9-11) is considered a functionally stable fixation. However, if a large-sized load bearing plate is used for osteosynthesis, it is exceptionally deemed to be a rigid fixation.

Just as with the fixation type, the surgeon chooses the preferred type, size and shape of plate used for osteosynthesis. Manufacturers offer dedicated mandibular osteotosynthesis
W tym czasie może, ale nie musi dojść do przemieszczenia odłamów wobec siebie, z tym że odłam dystalny, będąc unieruchomionym poprzez wiązanie międzyszczękowe, pozostaje nieprzemieszczony, natomiast zmianie może ulec położenie odłamu proksymalnego. Celem takiego działania jest prewencja zaburzeń w stawie skroniowo-żuchwowym. Efektem z kolei odkształcenie zespolenia w takim zakresie, na ile 
instrument sets suitable for different fixation types (Fig. 12), yet in most cases, except for the plates' shape differences as indicated above, the main principle of fixation remains unchanged: the fixation must be efficient enough to keep bone fragments in the correct position, allowing only for minimum movement across the fracture gap. As a result, mandibular stability is reduced at the early stages of osteosynthesis, which can promote more significant displacement of osteotomy segments in patients with occlusal discrepancies, leading to early postoperative relapse. Nevertheless, it offers more freedom and the potential for spontaneous correction of the proximal segment if it is displaced within the temporomandibular joint during osteotomy fixation.

These premises, i.e. the uncertainty as to the proximal segment positioning during the procedure, when the patient is anaesthetised and under the effect of muscle relaxants, were at the core of the fixation concept postulated by the research team from Munster University (Germany) [24]. The main concept is to ensure osteosynthesis using a soft titanium plate of a particular shape. After osteotomy segment stabilisation it is necessary to use rigid intermaxillary fixation for a few days. Osteotomy slippage may occur over that period. However, the distal segment, immobilised with intermaxillary fixation, remains in position while the proximal one may be displaced. Such management aims at preventing temporomandibular joint dysfunction. Its effect, though, is the deformation of fixation devices to an extent imposed by the movement of the proximal segment necessary to achieve its correct position within the temporomandibular joint.

As emphasized above, the surgeon is responsible for selecting suitable fixation devices. It should be remembered, though, that it is yet another factor affecting therapeutic success. Different BSSO-related difficulties and complications still keep occurring. Hence, it is important to know how to minimize the risk of failure by, e.g. appropriate selection of osteosynthesis material (fig. 13).

\section{THE FUTURE}

While observing the development of orthognathic surgery, simultaneous with the technological development of bone fixation materials, two main tendencies can be noticed: One of them is the tendency to use bioresorbable materials; their main advantage is that they do not need to be removed, and therefore the patient does not need an additional procedure. Despite numerous reports comparing the strength of bioresorbable materials to that of titanium [25], this tendency seems to be on the decline.

The other trend involves using custom-made implants, designed and manufactured using 3D technology, which perfectly fit the anatomical relationships of a given patient. Although the method is attracting an increasing number of supporters, its main disadvantage at the moment is the relatively high manufacture cost of custom-made implants, as compared to conventional osteosynthesis materials.

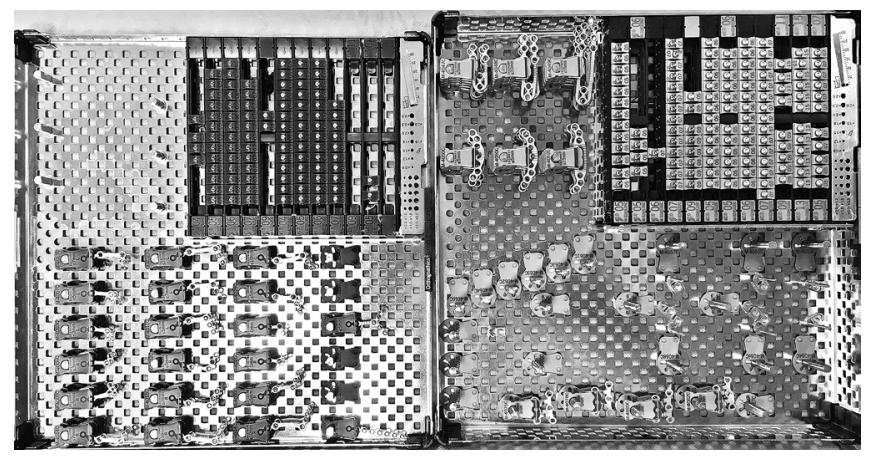

FIGURE 12. Osteosynthesis instrument set for orthognathic surgery RYCINA 12. Zestaw do osteosyntezy przeznaczony do chirurgii ortognatycznej

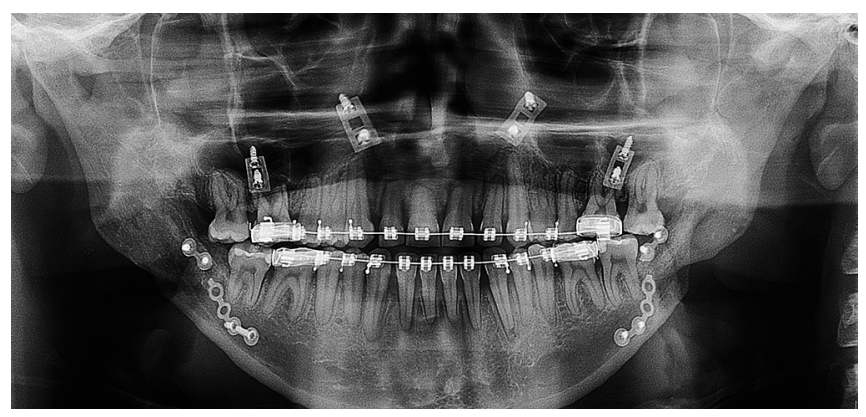

FIGURE 13. Broken fixation devices in a patient after BSSO as a result of postoperative non-compliance

RYCINA 13. Złamanie zespoleń po zabiegu BSSO na skutek braku stosowania się do zaleceń pooperacyjnych

jest konieczny ruch odłamu proksymalnego prowadzący do jego prawidłowej pozycji w stawie skroniowo-żuchwowym.

Jak już wcześniej podkreślano, wybór zespolenia należy do kompetencji chirurga, jednak należy pamiętać, że jest to tylko jeden z czynników mających na celu uzyskanie sukcesu terapeutycznego. Wciąż zdarzają się różne trudności i powikłania związane z zabiegami obustronnego strzałkowego rozszczepienia gałęzi żuchwy, dlatego warto mieć wiedzę o tym, jak minimalizować ryzyko niepowodzenia m.in. przez właściwy dobór materiałów do osteosyntezy (ryc. 13).

\section{JUTRO}

Obserwując rozwój chirurgii ortognatycznej, a tym samym technik dotyczących zespoleń odłamów kostnych, można zauważyć dwie główne tendencje. Jedną z nich jest sięganie po materiały bioresorbowalne, których główną zaletą jest brak konieczności ewakuacji, czyli kolejnego zabiegu operacyjnego. Pomimo że nie brakuje doniesień o porównywalnej do tytanu wytrzymałości materiałów resorbowalnych [25], tendencja ta wydaje się być w odwrocie. Drugi kierunek to indywidualne implanty wykonywane w technologiach 3D dopasowane do konkretnych warunków anatomicznych pacjenta. Metoda ta znajduje coraz więcej zwolenników, natomiast niewątpliwie obecnie największą jej niedogodnością jest relatywnie wysoki koszt produkcji indywidualnych implantów w porównaniu do klasycznych materiałów do osteosyntezy. 


\section{REFERENCES / PIŚMIENNICTWO}

1. Obwegeser HL. Orthognathic surgery and a tale of how three procedures came to be: a letter to the next generations of surgeons. Clin Plast Surg 2007;34:331-55.

2. Vrebos J, Dupuis C. From circumferential wiring to miniaturized plates and screws: the history of osteosynthesis of the mandible (with special reference to Dr. A. Lambotte). Eur J Plast Surg 2005;28:170-8.

3. Steinhauser E. Historical development of orthognathic surgery. J Craniomaxillofac Surg 1996;24:195-204.

4. Michelet F, Deymes J, Dessus B. Osteosynthesis with miniaturized plates in maxillofacial surgery. J Maxillofac Surg 1973;1:79.

5. Peri G, Jourde J, Menes R. De trous surtout pour reconstrniere certains segments du squelleter facial. Ann Chir Plast Esthet 1973;18:170.

6. Champy M, Lodde JP. Syntheses mandibulaires. Localisation des syntheses en function des contraintes mandibulaires. Rev Stomatol Chir Maxillofac 1976;77:971.

7. Loukota RA, Shelton JC. Mechanical analysis of maxillofacial miniplates. Br J Oral Maxillofac Surg 1995;33:174-9.

8. Eckelt U, Hlawitschka M. Clinical and radiological evaluation following surgical treatment of condylar neck fractures with lag screw. J Craniomaxillofac Surg 1999;27:235-42.

9. Meyer Ch, Martin E, Kahn JL, Zink S. Development and biomechanical testing of new osteosynthesis plate TCP $®$ designed to stabilize mandibular condyle fractures. J Craniomaxillofac Surg 2007;35:84-90.

10. McDonald WR, Stoelinga PJ, Blijdorp PA. Champy bone plate fixation in sagittal split osteotomies for mandibular advancement. Int J Adult Orthodon Orthognath Surg 1987;2:89-97.

11. Mommaerts MY, Abeloos JS, De Clerk CA, Neyt LF. Evaluation of the slot osteosynthesis technique in mandibular advancement. J Craniomaxillofac Surg 1994;22:281-5.

12. Foley WL, Beckman TW. In vitro comparison of screw versus plate fixation in the sagittal split osteotomy. Int J Adult Orthodon Ortognath Surg 1992;7:147-51.

13. Stoelinga PJ, Borstlap WA. The fixation of sagittal split osteotomies with miniplates: the versatility of a technique. J Oral Maxillofac Surg 2003;61: 1471-6.

14. Epker BN. Modifications in the sagittal osteotomy of the mandible. J Oral Surg 1977;35(2):157-9.

15. Booth DF. Control of the proximal segment by lower border wiring in the sagittal split osteotomy. J Maxillofac Surg 1981;9:126-8

16. MacIntosh R. Experience with the sagittal osteotomy of the mandibular ramus: a 13-year review. J Maxillofac Surg 1981;8:151-65.

17. Spiessl B. Osteosynthese bei sagittaler Osteotomie nach Obwegeser-Dal Pont. Fortschr Kiefer-Gesichtschir Bd 1974;18:145-8.

18. Luhr HG. Stabile Fixation von Oberkiefer-Mittelgesichtsfrakturen durch Mini-Kompressionsplatten. Dtsch Zahnfirztl 1979;34:851.

19. Van Sickels JE, Larsen AJ, Thrash WJ. Relapse after rigid fixation of mandibular advancement. J Oral Maxillofac Surg 1986;44:698-702.

20. Van Sickels JE, Tiner BD, Alder ME. Condylar torque as a possible cause of hypomobility after sagittal split osteotomy: report of three cases. J Oral Maxillofac Surg 1997;94:398-402.
21. Panula K, Somppi P, Finne K, Oikarinen K. Effects of orthognathic surgery on temporomandibular joint dysfunction. A controlled prospective 4-year follow-up study. Int J Oral Maxillofac Surg 2000;29:183-7.

22. Uckan S, Schwimmer A, Kummer F, Greenberg AM. Effect of the angle of the screw on the stability of the mandibular sagittal split ramus osteotomy: a study in sheep mandibles. Br J Oral Maxillofac Surg 2001;39:266-8.

23. Shetty V, Freymiller E, McBrearty D, Caputo AA. Functional stability of sagittal split ramus osteotomies: Effects of positional screw size and placement configuration. J Oral Maxillofac Surg 1996;54:1317-24.

24. Weingart D, Kleinheinz J, Joos U. Experiences with new adjustable bone fixation system for the sagittal ramus osteotomy. J Craniomaxillofac Surg 1996;24:124.

25. Stockmann P, Bohm H, Driemel O, Muhling J, Pistner H. Resorbable versus titanium osteosynthesis devices in bilateral sagittal split osteotomy of the mandible - the result of a two centre randomized clinical study with eight-year follow-up. J Craniomaxillofac Surg 2010;38:522-8.

\section{KOMENTARZ}

W artykule przedstawiona została metoda zabiegu operacyjnego opracowana przez H. Obwegesera, a przez następne pokolenia chirurgów szczękowo-twarzowych nazwana jego imieniem. Z pewnością praca ta spotka się z dużym zainteresowaniem wśród chirurgów ze względu na cenne wskazówki kliniczne w niej zawarte. Ponadto publikacja ta może być chętnie cytowana przez autorów prac z dziedziny chirurgii szczękowo-twarzowej, z uwagi na jej szeroki zakres i wielokierunkowy charakter.

dr hab. n. med. Katarzyna Grocholewicz

\section{KOMENTARZ}

Praca jest ciekawym opracowaniem przedstawiającym proces ewolucji w podejściu chirurgicznym do zespalania odłamów kostnych w chirurgii ortognatycznej. Swoją analizę Autorzy rozpoczynają krótkim rysem historycznym na temat różnych technik operacyjnych opierających się na osteotomii żuchwy, a następnie zespalaniu odłamów we właściwej pozycji. Jest to bardzo ciekawa część pracy, która z pewnością zainteresuje lekarzy zajmujących się tą dziedziną chirurgii czaszkowo-szczękowo-twarzowej, tym bardziej, że dodatkowo opatrzona jest dobrej jakości rycinami. 